deplored more deeply the loss of its leader, F. M. Balfour. As an embryologist his fame will depend chiefly on the clear interpretation he gave to some of the descriptions of the German school, and to the application he made of these to human embryology. An adept with his pencil as with his pen, he gave expression to his views in diagrams that probably for many a day will help the bewildered reader. Thus, though his name will not be associated with any one great discovery, Dr. Thomson will be recognised as a potent force in biological science during this century. His own work, his judicious criticisms, his personal influence, his encouragement to workers, all had an important part in moulding the present state of scientific thought on biological questions.

As to the man himself, those who knew him can testify to the kindly courtesy, to the simplicity of address, to the indescribable charm of his manner, to the warmth of his friendship. He was wise in counsel and adroit in reconciling differences amongst men. To this he owed much of his social power. His finely-moulded and venerable face will be much missed, but not more so than his wise advice at the council board or to the yonng man who has chosen a scientific career. JOHN G. MCKENDRICK

\section{QUINTINO SELLA}

BY the death of Signor Quintino Sella, to which we briefly referred last week, Italian science loses one of her strongest supporters and most earnest students. Although some of the best years of his life were devoted to statesmanship, his early writings on mineralogy were of sufficient solidity to establish for their author a very high reputation. These mineralogical memoirs, contributed chiefly to the Royal Academy of Sciences of Turin, were distinguished by a profound knowledge of crystallography. When the Geological Survey of Italy was about to be established, Signor Sella was commissioned to visit most of the European countries where Surveys were in operation, and in $186 \mathrm{I}$ he presented to Signor Cordova, then Minister of Agriculture, Industry, and Commerce, a valuable report, "Sul Modo di fare la Carta Geologica del Regno d'Italia." In collecting materials for that report he spent some time in this country, and took the warmest interest in the work of the Geological Survey. Ten years later he prepared an elaborate report on the mineral wealth of Sardinia. When the International Geological Congress was held at Bologna in $188 \mathrm{r}$, Signor Sella, as one of the most representative scientific men in Italy, was selected to act as the president; and those who had the advantage of attending that meeting carried away with them the most pleasant recollections of his courtesy. Signor Sella died at Biella in Piedmont on the I $4_{\text {th }}$ inst.

We direct attention to the letter from Prof. Hughes in connection with a memorial to the Italian savant.

\section{NOTES}

AT the final meeting, on Saturday last, of the General Committee of the International Fisheries Exhibition, the balance of the funds was disposed of. The surplus amounts to over 15,000l, and of this 10,000l. were allotted to alleviate the distress of widows and orphans of sea fishermen, while 3000 . were voted as an endowment to a society which is to be called "The Royal Fisheries Society," whose functions will be somewhat similar to those of the Royal Agricultural Society; the remaining 2000l. are kept in reserve.

Professors MARTens, Mendeléeff, and Minaieff are to attend the jubilee of Edinburgh University, as delegates from the University of St. Petersburg, and Prof. Rokhmaninoff as delegate from the University of Kieff.
THE great gold medal of the Paris Geographical Society has been awarded to the Deep-Sea Expeditions of the Talisman and Travailleur; a gold medal to M. Arthur Thoua:, for his journey across the desert of the Northern Chaco in search of the remains of the Crevaux Expedition ; a golu medal to M. Désiré Charnay, for his Central American explorations, and especially his researches in Yucatan.

A meetivg of the Governors of the City and Guilds of London Institute for the Advancement of Technical Education was held last week for the purpose of receiving the Annual Report of the Council. The chair was occupied by the Lord Chancellor. The Chairman, in moving the adoption of the Report, said that the Institution had arrived at a critical point of time, at a point of time at which he might remind them of the progress which things had made, but one, nevertheless, at which it became necessary that they should recognise the importance of proceeding energetically. With respect to the Central Institution, the buildings were nearly completed, and it was expected that the public opening of those buildings might take place in Tune of this year. It was proposed that four professors should be appointed to the Central Institution-viz. Professors of Chemistry, of Engineering, of Mechanics and Mathematics, and of Physics, the whole being superintended by a Board of Studies. There would be laboratories properly fitted up, and workshops and drawing offices, all with a view to supplying instruction which would combine the elements of those fundamental studies which underlay practical art. It was hoped that, as time went on, the number of exhibitions and scholarships, which would enable poor and meritorious students to obtain the benefits of the Institution, might increase. It was estimated that $9000 l$. a year would be available for the maintenance of the Institution, and that the fees of the students would amount to 2000l. That would give $\mathrm{I} \mathbf{1}, 000 \mathrm{l}$. as an expected present income. When the grant amountel to $10,000 \%$, and the students numbered from 150 to 200 , paying in fees $5000 l$., the income would be $15,000 \%$, and it was estimated that that amount would be required for maintaining the Institute in full working order. Passing from the Central Institution to Finsbury College, the Chairman said that the progress of that branch had been very satisfactory. During the past year it had instructed 799 persons, of whom roo had been day students and the rest students attend. ing the evening classes. The day students had to pass a preliminary examination in elementary mechanics, and there were six free scholars. The South London School had an attendance of 300 students. The candidates presented for examination this year were 2397 , being an increase over the former year of 425 , and the passes were 1498 , showing an increase over the former year of 276 . They came from 104 centres, showing an increase of seven centres; and they were examined, as in the former year, in thirty-seven subjects. What was still more remarkable was the rapid extension of the desire to have the benefit of these examinations, for there were now preparing for them 5862 students, being an increase over those who were unter similar preparation in the former year of no less than 1814. He recognised with gratitude the liberality with which they had been supported by the City Guilds and other bodies, and he could not but think that those who had helped them so far would help them still further. Since the report had been written, the Skinners' Company had increased their subscription for the year 1884 from $500 /$. to 1000 ., and their donation to the building fund from $20 \mathrm{col}$. to $3000 l$.

A CORRESPONDENT sends us the following:- "Thenew scheme for examinations for admission to Sandhurst which has been agreed upon (it appears) by the War Office and the Civil Service Commissioners must, if unmodified, work serious mischief to scientific education in public schools in which any pro- 